\title{
Sustainability of Guinea Fowl (Numidia meleagris) layers fed varying levels of Centrosema pubescent leaf meal.
}

\section{Sustentabilidad las gallinas de Guinea (Numidia meleagris) alimentadas con niveles variables de harina de hoja Centrosema pubescent.}

\author{
Ahaotu, E.O*1, Amajioyi, $\mathrm{N}^{1}$ and K.C. Okorie ${ }^{2}$ \\ ${ }^{* 1}$ Department of Animal Production Technology, Imo State Polytechnic Umuagwo, P.M.B \\ 1472, Owerri, Nigeria. \\ ${ }^{2}$ Department of Animal Science and Fisheries, Imo State University, P.M.B 2000, Owerri, \\ Nigeria \\ Corresponding author: Ahaotu, E.O; +234-803-8520-777; emmaocy@yahoo.com
}

\section{ABSTRACT}

An experiment was conducted to determine the effect of egg size on hatchability of Guinea fowl keets. Three different egg size groups (treatments): small ( $<39 \mathrm{~g}$ ); medium (39 - $42 \mathrm{~g}$ ) and large ( $>42 \mathrm{~g}$ )] were used in the experiment. Each treatment had three replicates of 10 eggs each. A complete randomized design was used for the experiment. Eggs were incubated with their sharp ends pointing downwards at $37.5-37.8^{\circ} \mathrm{C}$ and $60 \%$ relative humidity for 28 days. Thereafter, incubation parameters including hatchability (number of eggs that successfully hatched), dead in shells (DIS), clears, pips and keets with deformities evaluated. Data were analyzed using General Linear Model (GLM) of SAS. Medium sized eggs had significantly $(P<0.05)$ higher hatchability than small eggs. Also, medium sized eggs had lower pips. Egg size did not have effect on DIS, clears and deformities. The results of the present study showed that medium sized eggs (39 - $42 \mathrm{~g}$ ) hatched best in comparison to both small and large categories.

Keywords: Dead in shells, deformities, egg size, guinea fowl, hatchability, incubation

\section{RESUMEN}

Se realizó un experimento para determinar el efecto del tamaño del huevo sobre la capacidad de eclosión de los keets de las aves de Guinea. Tres grupos diferentes de tamaños 
de huevos (tratamientos): pequeños (<39 g); medio (39 - $42 \mathrm{~g}$ ) y grande (> $42 \mathrm{~g})$ ] en el experimento. Cada tratamiento tenía tres repeticiones de 10 huevos cada una. Se utilizó un diseño aleatorizado completo para el experimento. Los huevos se incubaron con sus extremos filosos apuntando hacia abajo a $37.5-37.8^{\circ}$ C y $60 \%$ de humedad relativa durante 28 días. A partir de entonces, los parámetros de incubación incluyen la incubabilidad (número de huevos que eclosionaron con éxito), muertos en caparazones (DIS), claros, pepitas y cepas con deformidades evaluadas. Los datos se analizaron usando el modelo lineal general (GLM) de SAS. Los huevos de tamaño mediano tuvieron una incubabilidad significativamente mayor $(P<0.05)$ que los huevos pequeños. Además, los huevos medianos tenían pepitas más bajas. El tamaño del huevo no tuvo efecto en DIS, despejes y deformidades. Los resultados del presente estudio mostraron que los huevos de tamaño mediano (39 - $42 \mathrm{~g}$ ) eclosionaron mejor en comparación con las categorías pequeñas y grandes.

Palabras clave: muerto en huevos, deformidades, tamaño del huevo, gallina de Guinea, incubabilidad, incubación.

\section{INTRODUCTION}

In the world today, the poultry industry has faced losses, with profit margin reduced by high cost of feed and other exigencies. Most poultry farmers spend about $75 \%$ of their capital on buying of feeds. One way it has become expedient to reduce the huge amount of money spent on feed is the incorporation of leaves that will act as feed additive, which invariably reduces cost. It has been noted (Chukwu et al., 2013) that while intensive system of poultry management prevents birds from being infected, it denies them of free access to fresh green leaves whose contributions as a feed addictive would enhance their productivity and growth. Succulent leguminous plants abound around homesteads and villages, believe to contain reasonable levels of certain valuable nutrients and these resources appear not to have been properly investigated and applied in poultry feeding.

The use of abundant green feeds as supplements of poor quality feeds could improve the performance of poultry. A good knowledge of the nutritional value of such plants in poultry nutrition would be valuable since they grow relatively easy and does not require much labour and cost hence this study. Centrosema pubescent leaves, with nutrient content of: dry matter $23.3 \%$, crude fibre $30.8 \%$, crude extract $3.9 \%$, crude protein $21 \%$ and total digestible nutrient $4.9 \%$ are commonly found in the tropics. Being a leguminous plant, it can be used as livestock feed addictive. The abundance of these succulent leguminous plants that contain reasonable levels of certain valuable nutrients appears not to have been fully explored (Amajioyi, 2017). It is believed that the use of abundant green leaves as feed supplements without doubt can improve the performance of poultry birds through enhanced growth. A good knowledge of the nutritional value of such leaves that grows relatively easy will help 
farmers to accomplish this goal. The objective of this experiment was to evaluate the effects of Centrosema pubescent leaves and its extract as a supplementary feed on the performance of guinea fowl layers.

Guinea fowl (Numidia meleagris) has wide distribution in Africa where it has distinct population among small holder farmers as shown in figures 1-7 (Nwafor and Onyebuchukwu, 2017). Its attractive plumage and value as a table bird with game type flavour and high meat to bone ratio has led to its worldwide acceptance (Ahaotu et al., 2018a). The birds are semi domesticated; thrive under semi-captive conditions in hot and cool climates. They are relatively disease-free and need little special care. Guinea fowl can be kept for meat and egg productions (Ahaotu, 2018). There are hardly and has no cultural barriers against consumption of guinea fowl products (Ahaotu et al., 2018b). The meat of guinea fowl is served extensively in hotels and restaurants because of its wild game flavor (Uche et al., 2014). Poultry production is unique and offers the quickest returns to investment outlay in livestock enterprises (Ahaotu et al., 2013). It has the highest feed conversion rates of 2:1 and produces the cheapest, commonest and best sources of animal protein (Ayorinde, 1991). Poultry production plays a significant role in the economic and social-life of the resource-poor households, contributing to cheap source of animal proteins and cash income (Ahaotu et al., 2017a). In sub-Saharan Africa, there are several species of poultry mainly represented by domestic indigenous chicken (Gallus gallus domesticus), guinea fowl (Numidia meleagris), duck (Cairina sp.) and turkey (Meleagris gallopavo); their distribution varies from one region to the other depending on both the physical and social environment (Ahaotu et al., 2012). In Nigeria, special species of poultry abound and they include chickens, guinea fowl, turkeys, ducks, and pigeons (Ahaotu et al., 2017b).

Leaf meal supplements have been included into the diets of poultry as a means of reducing high cost conventional protein sources and to improve profit margin (Nworgu et al., 2003). Forage meals and yellow maize are the natural sources of carotenoid (Ahaotu and Agbasu, 2015). However, the author noted that major constraints of leaf meal utilization in non-ruminants nutrition are relatively high fibre, low energy, anti-nutritional factors and reduced feed intake.

Centrosema pubescens is vigorous, trailing, twining and climbing perennial herb with trifoliate leaves and is fairly drought tolerant (Nworgu, 2004). The author noted that green matter yield of Centrosema pubescens varied from 13.5 to $40 \mathrm{t} / \mathrm{ha} / \mathrm{year}$. Nworgu and Ajayi (2005) reported that biomass and dry matter yield of Centrosema pubescens was 7.34 - 7.56 and 3.75 - $3.78 \mathrm{t} / \mathrm{ha}$ /year respectively. However, the use of Centrosema leaf meal (CLM) as protein supplement, in guinea fowl layers' nutrition is limited, unlike other leguminous and non-leguminous leaf meals (Gliricidia sepium, Leucaena leucocephala, Tridax procumbens and Manihot esculenta). Centrosema pubescens is in abundance in humid tropical environment. 


\section{MATERIALS AND METHODS}

The experiment was carried out at the Poultry Unit of Animal Production and Health Technology, Imo State Polytechnic Umuagwo, Nigeria. The experiment was carried out between July and August, 2016 with the mean annual rainfall of $1398 \mathrm{~mm}$ and mean monthly temperature of $22.71^{\circ} \mathrm{C}$ and average monthly relative humidity of $75.54 \%$ (IMLS, 2009). A total of 120 guinea fowl layer birds were used in the experiment.

Tender leaves of Centrosema pubescens were harvested from and around the paddocks in Poultry Unit of Animal Production and Health Technology, Imo State Polytechnic Umuagwo, The leaves were detached from the vines and stems and were dried at room temperature for 2-3 days to a moisture content of about 12\% (Amajioyi, 2017). The dried leaves were milled and ground using a hammer mill with a sieve and screen size of $2.0-3.0$ $\mathrm{mm}$. Samples of the leaf meals were collected for proximate and chemical analyses, while some were incorporated into the diets. Diets A, B, C, D and E contained 0, 2, 3, 4 and $6 \mathrm{~g} / \mathrm{kg}$ feed of each forage meal respectively.

Bird Management and Egg Collection: guinea fowl layers (the Pearl and Lavender) were housed in one pen and fed commercial layer diet for one week as stabilization period. Feed and water were given ad libitum (Amajioyi, 2017). A total of 90 eggs were obtained from Poultry Unit of Animal Production and Health Technology, Imo State Polytechnic Umuagwo Guinea Fowl Unit and were individually weighed and subjected to three weight groups: small (<39 g); medium (39 - $42 \mathrm{~g}$ ) and large ( $>42 \mathrm{~g}$ ). The three egg weight groups served as treatments. Each treatment was replicated three times with each replicate having 10 eggs (each treatment had 30 eggs). Prior to incubation, eggs were stored at room temperature up to seven days as this is the normal practice in the field (Figs 1-3).
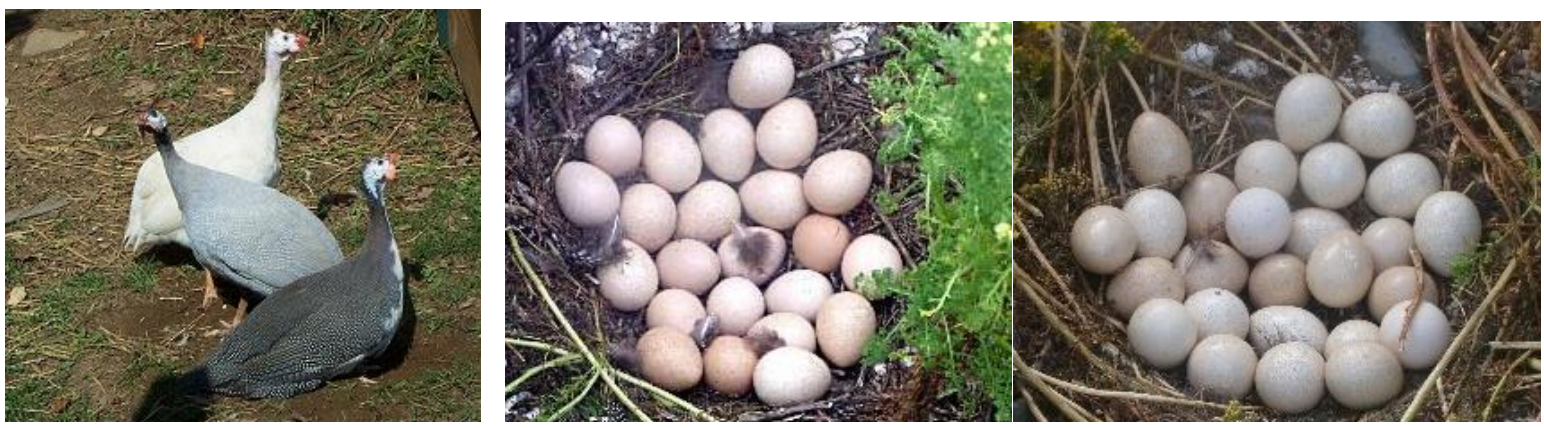

Figure 1. Varieties of guinea fowls and eggs. 

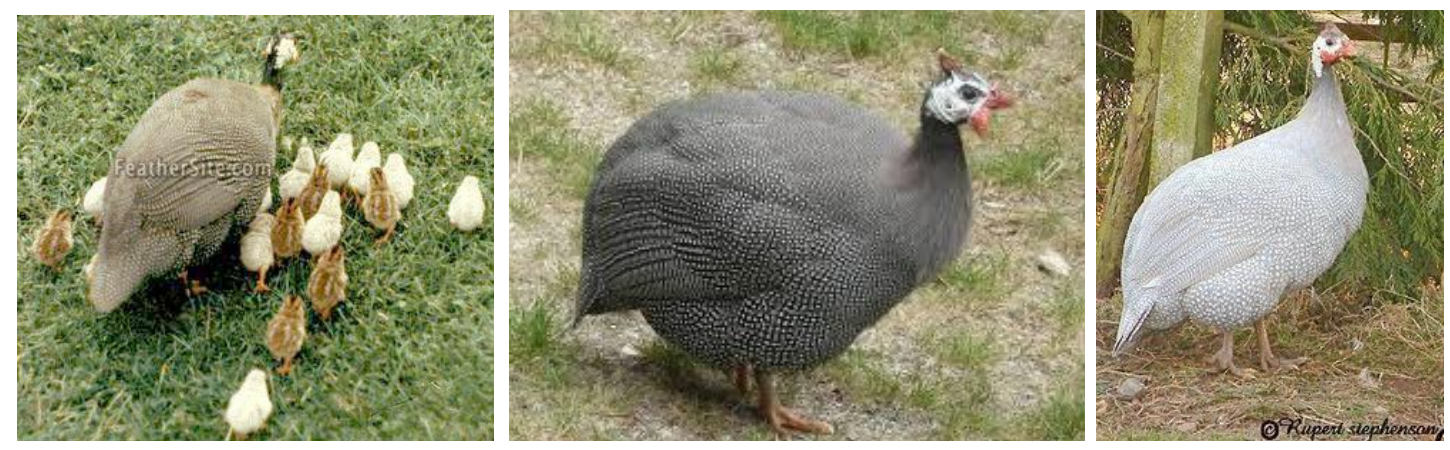

Figure 2. Typical guinea fowl hen and its keets (left), Pearl Guinea fowl (center) and Lavender Guinea fowl (right).
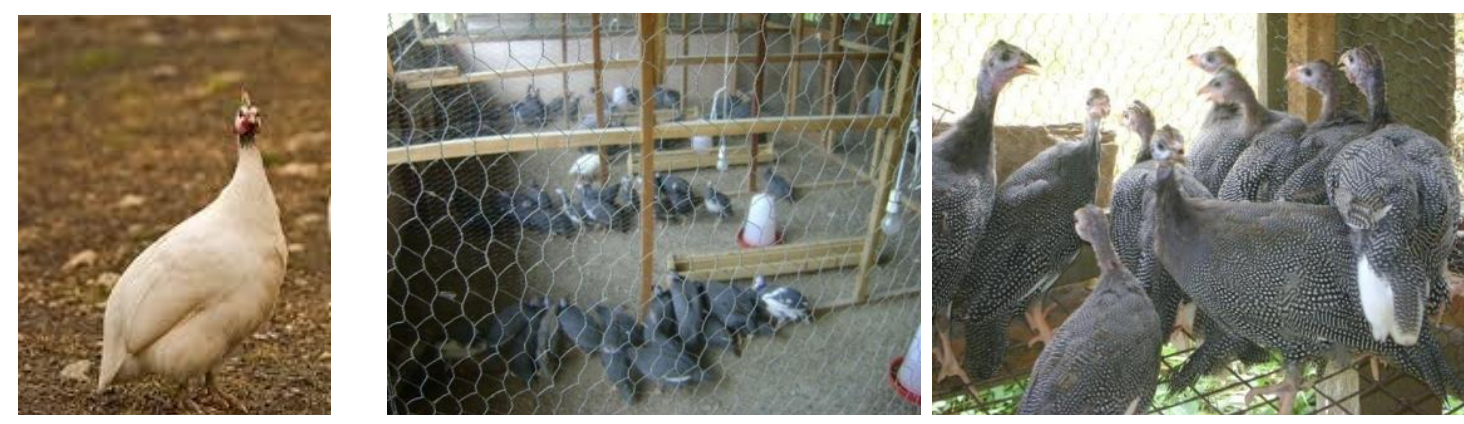

Figure 3. White guinea fowl (left) and nine-week old guinea fowls (center and right).

Measurement and data collection: the birds were individually weighted weekly for weight gain with a weighing balance. Observations of the physical appearance of the different groups were made to ascertain which of the five groups will mature first. The live weight of each bird from the five groups were taken randomly and recorded. Data on feed intake were taken on daily basis, while weight gains were taken on weekly basis. Routine management practices and medication were taken as and when due. Proximate and mineral composition of the test ingredients were determined by the procedures of (Carpenter and Clegg, 2000) and proximate composition of the diets was determined by the methods of (AOAC, 2005), while their metabolisable energy (ME) was determined by the methods of outlined by (Dougall and Bogdan, 2006). Gross energy of the test ingredients was estimated by the method of (AFRC 1990). Phytate was determined by the technique of (Igbedioh et al., 1994), while tannin was evaluated by the method outlined (Hagerman and LerI, 1983) and oxalate by the procedures of (Talapatra and Price, 1984).

Experimental Design and Statistical Analysis: the experimental design used was Completely Randomized Design (CRD). Data were analysed using the Statistical Analysis System (SAS, 2004). Treatment means were separated using Student t-test at $\mathrm{p}<0.05$ significant level (Gordon and Gordon, 2004). Data on feed intake feed, weight gain and feed conversion ratio were subjected to one-way ANOVA analysis of variance procedure of (AOAC, 
2005). Duncan's Multiple Range Test (Steel and Torrie, 1980) was used in assessing the significant differences among the treatments.

\section{RESULTS AND DISCUSSION}

Hatchability and Pips: the effect of egg size on hatchability of guinea fowl eggs is illustrated in Table 3. Hatchability for small and medium size eggs was significantly different $(p<0.05)$ from each other. Small eggs had significantly $(P<0.05)$ lower hatchability $(20.0 \%)$ compared to medium-size eggs (69.23\%). However, hatchability for small eggs did not differ significantly $(p>0.05)$ with that of large eggs ( $50.85 \%)$. Also, the hatchability for mediumsize and large eggs was not significantly different. These results are consistent with Ahaotu and Agunnanne, (2017) who reported $96.67 \%$ hatchability for medium size eggs from broiler breeders, while large eggs had the lowest value of $82.88 \%$ hatchability. Similarly, Oke et al., (2004) found that within the flock of guinea fowl, ducks, chickens, turkey, intermediate size eggs hatch better than small or large eggs. The authors attributed lower hatchability and fertility for all the egg categories to long storage ( 6 days after collection) of eggs before being set in the incubator (Ahaotu et al., 2017c). Also, Abiola et al., (2008) found that medium size (58- $64 \mathrm{~g}$ ) guinea fowl layer eggs had significantly higher hatchability than small eggs (<59 g). In disagreement with the present findings, Amajioyi (2017) in Imo State, Nigeria reported higher percentage hatchability of $72.8 \%$ and $73.6 \%$ for guinea fowl eggs that weighed on average 31.4 and $31.8 \mathrm{~g}$, respectively, which were not significantly different from each other. However, medium-sized eggs produced chicks with higher $(p<0.05)$ hatchweight than small and large-sized eggs.

The results revealed that the leaf meals (CLM) studied is rich in crude protein (CP), crude fibre (CF) and in ash. The CLM are rich in calcium, potassium and phosphorus. The LM has moderate concentrations of magnesium, sodium; zinc and iron. The concentrations of oxalate, phytate and tannin are presented in Table 1a. The most available anti-nutritional factor was tannin. Feed intake, weight gain and feed conversion ratios of guinea fowl layers fed graded levels of Centrosema pubescens leaf meal were significant $(p<0.05)$ (Table 2$)$. Dietary inclusion (Table 1b) of 2 to $6 \%$ CLM supplements for guinea fowl layers resulted to increased feed intake and depression in both weight gain and feed conversion ratio compared to the birds placed on control diet. However, the best performance for guinea fowl birds in terms of weight gain was observed on the birds placed on $2 \%$ CLM, which also had elevated feed intake. Dietary inclusion of 3.0 to $6.0 \%$ CLM for guinea fowl birds resulted to elevated feed intake which depressed at $6.0 \%$ (Table $1 \mathrm{~b}$ ). 
Table 1a. Proximate Chemical Composition of Experimental Test Ingredients (\% DM Basis).

Composition

Dry mater

Crude protein

Crude fibre

Ether extracts

Ash

Nitrogen free extract (NFE)

Calcium

Potassium

Phosphorus

Magnesium

Sodium

Zinc (mg/kg/DM)

Iron $(\mathrm{mg} / \mathrm{kg} / \mathrm{DM})$

Oxalate $(\mathrm{g} / 100 \mathrm{~g} D \mathrm{DM})$

Phytate $(\mathrm{g} / 100 \mathrm{~g} D M)$

Tannin (g/100g DM)

Gross energy (kcal/kg)* Centrosema Leaf Meal
88.89

23.24

8.20

3.32

9.14

55.50

1.22

1.85

0.54

0.30
40.01

20.01

0.037

0.48

2.81

4354

Table 1b: Composition of experimental Diets

\begin{tabular}{lllllll}
\hline Parameters & $0 \%$ & $20 \%$ & $30 \%$ & $40 \%$ & $60 \%$ \\
\hline Maize & 65.50 & 65.50 & 65.50 & 65.50 & 65.50 & \\
Palm kernel cake & & 25.00 & 25.00 & 25.00 & 25.00 & 25.00 \\
CLM & 0.0 & 2.0 & 3.0 & 4.0 & 6.0 & \\
Blood meal & 8.3 & 6.3 & 5.3 & 4.3 & 2.3 \\
Lysine & 0.25 & 0.25 & 0.25 & 0.25 & 0.25 \\
Methionine & 0.25 & 0.25 & 0.25 & 0.25 & 0.25 \\
Premix & 0.45 & 0.45 & 0.45 & 0.45 & 0.45 \\
Common Salt & 0.25 & 0.25 & 0.25 & 0.25 & 0.25 \\
\hline
\end{tabular}

Variation in the results could be ascribed to the age of cutting of the Centrosema pubescens leaves, as older leaves are more fibrous (Nworgu, 2004). However, Esonu et al., (2003) reported that broiler chicks fed on 0.0, 5.0 and 10.0 percent Microdesmis puberula leaf meal had final body weight gain of $600.00,550.00$ and $551.00 \mathrm{~g} / \mathrm{bird}$, respectively which agrees with the present study. Similarly, Nsoso et al., (2003) reported that guinea fowl layers 
fed on $0.0,5.0,10.0$ and $15.0 \%$ CLM supplements had final body weight of 1690, 1630, 1490 and $1280 \mathrm{~g} / \mathrm{bird}$, respectively and concluded that guinea fowl birds can tolerate up to $15 \%$ CLM supplement without mortality, which is contrary to the present study, as the author reported non-significant $(p<0.05)$ difference among the treatments. Poor performance of weight gain and FCR in the present study could be attributed to the presence of some antinutritional factors (Nworgu et al., 2012 and Moreki et al., 2013) which resulted to poor feed digestibility and utilization.

Feed and water intakes increased significantly $(p<0.05)$ with dietary inclusion of CLM. Total feed intake in this study $(46.35,50.28,50.06,49.94$ and $49.96 \mathrm{~g} / \mathrm{bird}$ ) is in harmony with the report of Nworgu et al., (2005), but lower than that reports of (Ayorinde, 1991 and Ayorinde et al., 1989). Average daily water intake (100.10, 110.11, 106.31, 108.02 and 108.54) and feed water ratio are similar with the results of Ahaotu and Agunnanne, (2017).

Higher feed intake attributed to higher fiber content of the CLM as the birds eat to satisfy their energy level (Omeje et al., 1997). The cost of feed per kilograms live weight gain was best in control (N91.86/kg), while on the guinea fowl birds fed $6.0 \%$ CLM supplement, it was NI07.59 - NI08.57/ kg. The cost of feed per kilograms live weight gain reported here is in agreement with the observation of Nworgu et al., (2005) (N99.31 - NI29.49/kg). No mortality was recorded, hence guinea fowl layers can tolerate up to $6.0 \%$ CLM, although maximum dietary inclusion of CLM for optimal performance of broiler chicks should not exceed $3.0 \%$ (Table 2).

Inclusion of CLM at $6.0 \%$ reduced cost of one kilogram of formulated feed by $\mathrm{N} 4.0$ over the control, although the reduction could not be justified in terms of profit and cost of feed per kilogram live weight gain. The birds fed on CLM control diet had net profit of N4.11/ per bird, while those placed on 3 and 4\% CLM had N2.66 and N0.84 profit per bird, unlike the guinea fowl birds fed $6 \%$ CLM which resulted to average loss of N20.39/bird due to depressed body weight. The profit levels reported here were lower than those reported by Nworgu (2007). Gross ratio was best $(0.98: 1)$ for the birds placed on control diet and for every 98 kobo spent the farmer gets N1.00 unlike the birds placed on 6\% CLM, where a farmer had a loss of N0.12 - N0.34 for every N1.00 spent. The significance of this study is that CLM should not be included in the diet of guinea fowl layers at more than $6 \%$ as inclusion of more than $6 \%$ resulted to negative growth rate and negative profit margins unlike the result of some authors. 
Table 2. Performance of Guinea Fowl Layers fed experimental diets.

\begin{tabular}{lllllll}
\hline Parameters & & \multicolumn{4}{c}{ Dietary Treatments } \\
& A & B & C & D & E & SEM \\
Initial live weight (g/bird) & 85.41 & 84.00 & 84.50 & 85.41 & 84.30 & - \\
Final body weight (g/bird) & $745.80^{\mathrm{a}}$ & $745.40^{\mathrm{a}}$ & $710.04^{\mathrm{c}}$ & $640.9^{\mathrm{b}}$ & $627.2^{\mathrm{d}}$ & 0.89 \\
Mean body weight gain (g/bird) & $660.39^{\mathrm{a}}$ & $661.40^{\mathrm{a}}$ & $625.90^{\mathrm{b}}$ & $555.49^{\mathrm{c}}$ & $542.90^{\mathrm{c}}$ & 1.04 \\
Average daily weight gain (g/bird) & $18.87^{\mathrm{a}}$ & $18.89^{\mathrm{a}}$ & $17.88^{\mathrm{ab}}$ & $16.6^{\mathrm{b}}$ & $15.51^{\mathrm{c}}$ & 0.89 \\
Total feed intake (g/bird) & $1622.40^{\mathrm{b}}$ & $1759.54^{\mathrm{a}}$ & $175218^{\mathrm{a}}$ & $1748.14^{\mathrm{a}}$ & $1748.98^{\mathrm{a}}$ & 0.90 \\
Average daily feed intake (g/bird) & $46.35^{\mathrm{b}}$ & $50.28^{\mathrm{a}}$ & $50.06^{\mathrm{a}}$ & $49.94^{\mathrm{a}}$ & $49.96^{\mathrm{a}}$ & 1.00 \\
Feed conversion ratio (FCR) & $2.46^{\mathrm{c}}$ & $2.66^{\mathrm{ab}}$ & $2.80^{\mathrm{b}}$ & $3.15^{\mathrm{a}}$ & $2.79^{\mathrm{b}}$ & 0.23 \\
Total water intake (ml/bird) & $3502.82^{\mathrm{d}}$ & $3854.22^{\mathrm{a}}$ & $3720.84^{\mathrm{c}}$ & $3781.57^{\mathrm{b}}$ & $3798.90^{\mathrm{b}}$ & 1.09 \\
Average daily water intake (ml/bird) & $100.10^{\mathrm{c}}$ & $110.11^{\mathrm{a}}$ & $106.31^{\mathrm{b}}$ & $108.02^{\mathrm{ab}}$ & $108.54^{\mathrm{ab}}$ & 0.87 \\
Feed: Water intake ratio & $1: 2.16$ & $1: 2.19$ & $1: 2.12$ & $1: 2.08$ & $1: 2.17$ & - \\
Cost of I kg of feed (N/kg) & 37.40 & 36.10 & 35.30 & 34.50 & 33.40 & - \\
Cost of feed consumed (N/kg) & 60.67 & 6352 & 61.85 & 60.31 & 58.41 & - \\
Cost of feed per kg live weight & 91.80 & 96.04 & 93.81 & 108.57 & 107.59 & - \\
(N/kg) & & & & & &
\end{tabular}

TABLE 3: Means and Standard Errors for Incubation Parameters

\begin{tabular}{|c|c|c|c|}
\hline Treatment & Dead in shells & Pips & Clears \\
\hline \multicolumn{4}{|l|}{ Deformities } \\
\hline Small (<39 g) & $0.2000(0.1999) b$ & $0.2000(0.1999)^{a}$ & $0.2000(0.1999)^{a}$ \\
\hline $0.2000(0.1999)^{a}$ & $0.2000(0.1999)^{a}$ & & \\
\hline Medium $(39-42 \mathrm{~g})$ & $0.6923(0.0923)^{a}$ & $0.1538(0.0721)^{a}$ & $0.0000(0.0000)^{b}$ \\
\hline $0.1154(0.0639)^{a}$ & $0.0385(0.0385)^{a}$ & & \\
\hline Large $(>42 \mathrm{~g})$ & $0.5085(0.0656) a b$ & $0.1525(0.0453)^{a}$ & $0.0678(0.0291)^{a b}$ \\
\hline $0.1186(0.0428)^{a}$ & $0.1525(0.0679)^{a}$ & & \\
\hline
\end{tabular}

\section{DISCUSSION}

The leaf meals (LM) are moderate in crude fibre (CF). The relatively high CP and low CF with high concentration of ash will necessitate the use of CLM as protein and mineral supplements in guinea fowl layer production. Hetland et al., (2017) revealed that some tropical legumes have higher nutritive value and that the availability of the component amino 
acids in the small intestine would be more when the leguminous forage materials are fed dried than when fresh. The CP value of CLM in this study is higher than the report of (Aletor and Omodara, 1994), but similar to that of (Nworgu et al., 1999) (19.6\%) and (Raharjo et al., 1986) (21.4\%). Nwafor and Onyebuchukwu, (2017) reported that Centrosema pubescens contained $20.0 \% \mathrm{CP}$, with CF of $10.0 \%$. These authors further noted that Centrosema pubescens harvested at 12 weeks after planting contained $18.70 \% \mathrm{CP}, 11.80 \% \mathrm{CF}, 6.98 \%$ ash and other extract of $4.42 \%$. The gross energy (GE) of the CLM was $4354 \mathrm{Kcal} / \mathrm{Kg}$.

These values are in harmony with the reports of (Nworgu et al., 2005) who reported that tropical legumes have GE of $4326 \mathrm{Kcal} / \mathrm{Kg}$. Nwafor and Onyebuchukwu (2017) reported that GE of CLM was $3885 \mathrm{Kcal} / \mathrm{kg}$. The variations in the CP, CF GE and EE could be attributed to the age of cutting, climatic conditions, methods of processing and analyses. Concentrations of calcium and potassium which were highest in the CLM are in line with the discovery of (Amajioyi, 2017) who stated that calcium, potassium and sodium were the most available mineral elements in forage meals. Calcium and phosphorus concentrations for CLM in this study are higher than that reported by (Skerman et al., 1988) whose value were 0.72 and $0.23 \%$ for calcium and phosphorus, respectively, but they are in harmony with the reports of (Omeje et al., 1997) who reported $0.78-1.36 \%$ for calcium and $0.13-0.45 \%$ for phosphorus. The diets for the guinea fowl birds met the nutritional requirements of the birds and are in line with standards of (Nsoso et al., 2003). Dietary inclusion of Centrosema pubescens meal in the diets of guinea fowl layers significantly $(p<0.05)$ resulted to reduced feed intake. Feed intake increased with increased dietary inclusion of CLM supplements.

This result is contrary to the report of (Kusina et al., 2012) who concluded that $5-10 \mathrm{~g}$ $\mathrm{CLM} / \mathrm{kg}$ feed resulted to elevation of weight gain. However, this result agrees with earlier observations that dietary inclusion of leaf meal of Bambara nut (Ahaotu et al., 2016) and (Ononiwu et al., 2017) depressed feed intake, weight gain and feed conversion ratio. Dietary inclusion of $3 \mathrm{~g} \mathrm{CLM} / \mathrm{kg}$ feed for guinea fowl layers resulted to 26.34 and $9.60 \%$ increases in weight gain over control and $4 \mathrm{~g} C L M / \mathrm{kg}$ feed, respectively. However, for guinea fowl birds, the increase in weight gain for $3 \mathrm{~g} \mathrm{CLM} / \mathrm{kg}$ feed was $56.12 \%$ due to prolonged feeding, as the feeding was continuous from grower to layer phase. These results are contrary to the reports of (Yildirim, 2012 and Naandam et al., 2012) but agree with the findings of (Nwagu, 1997; Nworgu and Faphunda, 2002) when guinea fowl birds were fed graded leaves of Mimosa invisa.

Dead in shell, clears and deformities: egg size had no effect on DIS, clears and deformities (Table 3). However, in this study small eggs had numerically higher DIS, clears and deformities than other egg sizes. As shown in Table 3, the results obtained on the number of DIS did not follow any particular trend. However, DIS values ranged from 15.25 to $20 \%$. The result on DIS in the current study is inconsistent with Abiola et al. (2012) who reported that large eggs had the lowest egg weight loss hence resulting in the likelihood of 
embryos drowning thus increasing embryo mortalities than both small and medium sized egg categories.

Clears (infertile eggs) in this study followed no particular trend. The clears for small, medium and large sized eggs were $23 \%, 11.5 \%$ and $11.9 \%$, respectively. Medium sized eggs had numerically lower clears compared to other egg sizes. The studies carried out by (King'ori, 2011 and Wilson, 1991) attributed infertility of eggs to a number of factors including lethal genes, insufficient nutrients in the egg and exposure to conditions that do not meet the needs of the developing embryo. Although small, medium and large sized eggs showed no significant difference in terms of keets' deformities (Table 3), medium sized eggs had significantly lower keets deformities compared to other egg sizes.

As conclusion the Centrosema pubescent meal (CLM) studied are rich in crude protein $(23.24 \%)$ and ash (9.14\%). The most available mineral elements were potassium (1.85\%) and calcium (1.22\%). Centrosema pubescens leaf meal (CLM) is the most outstanding in mineral profile, nutritive value and chickens performance. Dietary inclusion of $6 \mathrm{~g} \mathrm{CLM} / \mathrm{kg}$ feed resulted to depressed feed intake and growth performance in the guinea fowl birds. For improved performance and adequate growth rate, it is advisable to include $3 \mathrm{~g} \mathrm{CLM} / \mathrm{kg}$ feed in the diets of guinea fowl birds. Three percent dietary inclusion of CLM is adequate for guinea fowl birds, although it was not significantly $(p>0.05)$ different from control. Inclusion of more than $6 \%$ CLM in the diets of guinea fowl birds significantly $(p<0.05)$ depressed weight gain and FCR and resulted to negative profit margin. More water should be provided for guinea fowl birds when fed CLM supplements. Also the range of egg size used in this study had a significant effect $(p<0.05)$ on hatchability and pips of guinea fowl keets of Pearl and Lavender strains. The study showed that for optimum hatchability, medium size eggs (39-42 g) should be used instead of large ( $>42 \mathrm{~g}$ ) and small eggs ( $<39 \mathrm{~g})$ which had less hatchability percentages. Egg size had no effect on DIS, clears and deformities. It is concluded from the present results that medium size eggs resulted in higher hatchability compared to small and large egg sizes.

\section{REFERENCES}

Abiola, S. S., Meshioye, O. O., Oyerinde, B. O and Bamgbose, M.A (2008). Effect of egg size on hatchability of broiler chicks. Archivos Zoo Technica, 57(217): 83-86.

AFRC (1990). Agricultural and Food Research Council. Pp 750.

Ahaotu, E.O., Ihenacho, R.A. and Agunanne, U.T (2018a). Characteristics and Performance of Guinea Fowl Production Under Improved and Extensive Management Practices in Imo State, Eastern Nigeria. Journal of Poultry Science and Technology, 6 (1): 14-19.

Ahaotu, E.O, Emeribe, E.O and Akinfemi, A. (2018b). Carcass and Performance Characteristics of Finisher Broiler Birds Fed Jack Bean (Canavalia ensiformis) Sievate 
Fortified with Exogenous Enzyme. Journal of Meat Science and Technology, 06 (2): 19-24.

Ahaotu, E.O and Agunanne, U.T (2017). Egg production pattern in Anthony patience farms, Atta-Ikeduru, Imo state, Nigeria: Influences on the phase of production and the estimated period of oviposition. Proceeding 6th ASAN-NIAS Joint Annual Meeting. Sept 10-14. pp. 375-380.

Ahaotu, E.O., Okonkwo, J.C and Madubuike, F.N. (2017a). Performance and Carcass Characteristics of Starter Broiler Birds Fed Processed Wild Cocoyam Corm Meal (Colocosia esculenta . L). Proceedings of the First Conference of Faculty of Agriculture and Veterinary Medicine Held at Imo State University, Owerri, Nigeria. Dec. 4-6, 2017. Pp 279-287

Ahaotu, E. O., Ihenacho, R. A., Ike, A. and Ihenacho, A. C. (2017b). Socio-economic and management practices of Duck in Imo State. A study of Orlu Local Government Area, Imo State, Nigeria. Direct Journal of Agriculture and Food Science, 5: 250-255.

Ahaotu EO, Ihenacho RA and Ayo - Enwerem CM (2017c). Performance of Nera black layer birds fed feather meal supplemented with fish meal. Proceeding 6th ASAN-NIAS Joint Annual Meeting. Sept 10-14. pp. 608-611.

Ahaotu, E.O, Okonkwo, V.N., Okorie, K.C and Akinfemi, A. (2016). Effect of Bambara Nut Sievate Supplemented Exogenous Enzymes on Haematology and Serum Biochemical Value of Finisher Broiler Birds. Book of Proceedings of Academic Conference on Positioning Sub-Saharan Africa for Development in the New Development. 22-23 $3^{\text {rd }}$ June, 2016, Cambridge Hall, University of Ghana, Legon Campus, Accra. Vol. 9 (1): 32 -39 .

Ahaotu, E.O (2018). Performance of Guinea Fowl Keets Reared in Improved Extensive System in Anthony Patience Farms, Atta - Ikeduru, Imo - State, Nigeria. Veterinary Research International, 6: 25-31.

Ahaotu, E.O., Umoh, G., Onwueagba, A.E., Chukwu, A.O. and Iwuanyanwu, U.P (2013). Guinea Fowl Keets Performance Under Improved And Extensive Conditions In Anthony Patience Farms, Atta - Ikeduru, Imo - State, Nigeria. Inter J Agri Biosci, 2 (2): 82-86.

Ahaotu, E.O., Ehirim, V.I., Nkwocha, G.A., Iwuanyanwu, U.P and Ihezuo, J.P. (2012). Carcass and performance characteristics of khaki Campbell ducklings fed high fiber rice milling waste. Proc. $17^{\text {th }}$ Ann. Conf. Animal Science Association of Nigeria., $9^{\text {th }}$ $13^{\text {th }}$ September, 2012, Abuja, Nigeria, Pp 326-329. 
Ahaotu, E.O. and Agbasu, C.A. (2015). Evaluation of the stocking rate on growth performance, carcass traits and meat quality of male Peking ducks. Scientific Journal of Biological Sciences. 4(3): 23-29. Doi: 10.14196/sjbs v413.

Aletor, V.A and Omodara, O.A (1994). Studies on some leguminous browse plant, with particular reference to their proximate, mineral and some endogenous anti-nutritional constituents. Animal Feed Science and Technology. 46: 343-348.

Amajioyi, N. (2017). Sustainability of Guinea Fowl (Numidia meleagris) layers fed varying levels of Centrosema pubescent leaf meal. Hnd Research Project, Department of Animal Production and Health Technology, Imo State Polytechnic Umuagwo, Nigeria. $65 \mathrm{pp}$.

AOAC. Association of Official Analytical Chemists (2005). Official Methods of Analyses.15th Edition, Washington, D.C.

Ayorinde, K.L (1991). Guinea fowl (Numidia meleagris) as protein supplement in Nigeria. World Poultry Science Journal, 47: 21-26.

Ayorinde, K.L., Ayeni, J.S.O. and Oluyemi, J.A. (1989). Laying characteristics and reproductive performance of four indigenous helmeted guinea fowl varieties (Numidia meleagris galeata pallas) in Nigeria. Tropical Agriculture (Trinidad) 66: 277-280.

Carpenter, K.J and Clegg, K.M (2000). The metabolisable energy of poultry feed stuff in relation to their chemical composition. Journal Science, Food and Agriculture, 77:4548.

Chukwu, A.O , EO Nwachukwu, PN Onu and EO Ahaotu (2013). Economy and Performance of Guinea Fowl raised on Free Range System in Ikeduru Local Government Area, Imo State, Nigeria. Inter J Lib Manage Soc Sci, 1(1): 1-4.

Dougall, HW and Bogdan, AV (2006). The chemical composition of some leguminous plants grown in the herbage nursery at Kitale, Kenya. East African Agricultural and Forestry Journal, 82:45-49.

Esonu B.O, Iheukwumere F.C, Iwuji T.C, Akanu N and Nwugo O.H (2003). Evaluation of Microdesmis puberula Leaf meal as feed ingredient in broiler starter diets. Nigerian Journal of Animal Production, 30: 3-8.

Gordon, S. P and Gordon, F. S. (2004). Contemporary Statistics: A computer Approach. McGraw - Hill Publishers, U.S.A. 98-112pp.

Hagerman, A.E and LerI, G (1983). Precipitation method for the qualitative determination of tannins. Journal of Agriculture, Food and Chemistry. 26:809-812.

Hetland, H., Ayo -Enwerem, C.M., Ahaotu, E.O., Oji, U.I and Bryden, W.L (2017). Chemical Composition and Potential Degradability of Some Selected Multipurpose Fodder Trees and Shrubs of the Humid Zone. Proceedings of the First Conference of Faculty of 
Agriculture and Veterinary Medicine Held at Imo State University, Owerri, Nigeria. Dec. 4-6, 2017. Pp 294-304.

Igbedioh, S.O, Olugbemi, K.T.A and Akpapunam, M.A (1994). Effect of processing methods on phytic acid level in bambara nut and pigeon pea. Chemistry. 50:147-151.

Imo State Ministry of Lands and Survey (IMLS) (2009). Longitudes and Latitudes locations of Umuagwo, Ohaji / Egbema Local Government Area of Imo State, Nigeria.

King'ori, A.M (2011). Review of the factors that influence egg fertility and hatchability in poultry. International Journal of Poultry Science, 10: 483-492.

Kusina, N. T., Saina, H., Kusina, J. F and Lebel, S (2012). An insight into guinea fowl rearing practices and productivity by guinea fowl keepers in Zimbabwe. African Journal of Agricultural Research, Vol. 7(25), pp.3621-3625.

Omeje, S.I, Odo, B.I and Eguw, P.O (1997). The effects of Centrosema pubescens as leaf meal concentrate for broiler birds. Proceeding of 22nd Annual Conference of NSAP held at Abubakar Tafawa Balewa University, Bauchi - Nigeria Pp 136 - 137.

Moreki, J.C and Mothei, K.M (2013). Effect of egg size on hatchability of guinea fowl keets. International Journal of Innovative Research in Science, Engineering and Technology, 2: $5480-5483$.

Naandam, J., and Issah, G. B (2012). Hatchability of guinea fowls eggs and performance of keets under the traditional extensive system in Tolon-Kumbungu district of Ghana. Online Journal of Animal Feed Research, 2: 253-257.

Nsoso, S. J. G., Seabo, M., Kgosiemang, J., Molatlhegi, S. G., Mokobela, M., Chabo, R. G and Mine, O. M (2003)., Performance of progeny of wild and domesticated guinea fowl (Numidia meleagris) in Southern Botswana. South African Journal of Animal Science, 4: 46-5.

Nwafor, C.K and Onyebuchukwu, P.A (2017). Carcass, Organ Weights and Egg Quality Characteristics of Guinea Fowl Layers Fed Varying Levels of Butter fly Pea (Centrosema pubescent) Leaf Meal. Hnd Research Project, Department of Animal Production and Health Technology, Imo State Polytechnic Umuagwo, Nigeria. 79pp.

Nwagu, B. I (1997). Factors affecting fertility and hatchability of guinea fowl eggs in Nigeria. World's Poultry Science Journal 7: 279-286

Nworgu, F.C, Adebowale, E.A, Oredein, O.A and Oni .A (1999). Prospect and economics of broiler production using two plant protein sources. Tropical Journal of Animal Science. 2: 159-166.

Nworgu, F.C and Faphunda, J.B (2002). Performance of broiler chicks fed mimosa (Mimosa invisa) leaf meal supplements. Proceeding of 27th Ann. Conf. of Nigerian Society of Animal Production (NSAP), Held at the Federal University of Technology Akure, Nigeria on the 17th - 21st March, 2002. Aletor V.A. and Onibi G.E. (eds.). 2002;128-131. 
Nworgu F.C, Egbunike G.N, Ononogbu C.E, Fapohunda J.B and Ogbonna J.U (2003). Effect of mimosa (Mimosa invisa) leaf meal supplements on broiler finishers performance. Proceedings of the 8th Annual Conf. of Animal Science Association of Nigeria. Held at Federal University of Technology, Minna, Niger State on September 16 - 18th.Olatunji, EA, Ayanwale BA, Shiawoya Ed. And Aremu A (eds).:36-39.

Nworgu, F.C, Oduola, O.A, Alikwe, P.C and Ojo, S.J (2012). Effect of basil (Ocimum gratissimum) leaf supplement on initiation of egg laying and egg quality parameters of growing pullets. Journal of food, Agriculture and Environment 10: 337-342.

Nworgu F.C (2004) Utilization of forage meal supplements in broiler production. Ph. D Thesis submitted to University of Ibadan, Ibadan - Nigeria Pp. 136 - 146.

Nworgu F.C, Olatubosun L.O, Egbunike G.N and Ajayi I.O (2005). Effects of Pueraria (Pueraria phaseoloides) leaf meal supplements on the performance of broiler chicks. Proceeding of 8th Annual Conference of Animal Science Association of Nigeria (ASAN) held at University of Ado-Ekiti Nigeria on the 12 - 15th September, 2005 Pp $148-151$.

Nworgu F.C and Ajayi F.T (2005) Biomass, dry matter yield, proximate and mineral composition of forage legumes grown as early dry season feeds. Livestock Research for Rural Development 17: Article \#121.

http://www.Irrd.org/Irrd17/11/nwor17121.htm.

Nworgu F.C (2007) Economic importance and growth rate of broiler chickens served fluted pumpkin (Telfaria occidentalis) leaves extract. African Journal of Biotechnology 6: 167-174.

Oke, U . K, Herbert, U and Nwachukwu, K (2004). Association between body weight and some egg production traits in the guinea fowl (Numidia meleagris galeata Pallas). Livestock Research for Rural Development. 16 (9):10.

Ononiwu, C.C, Ahaotu, E.O, Okonkwo, V.N., Ayo-Enwerem, C.M and Botchway, H. (2017). Effects of Bambara Nut Sievate Fortified Exogenous Enzyme on Performance and Carcass Characteristics of Finisher Broiler Birds. Proceedings of the $20^{\text {th }}$ Biennial Conference, Ghana Society of Animal Production (GSAP), 1-5 August, 2017. Sasakawa Centre, University of Cape Coast, Ghana Pp 73-80.

SAS Institute (2004). SAS User's Guide: Statistics. Version 9.1 ed. SAS Inst. Inc., Cary, NC.

Skerman, P.I, Cameroon, D.G and Riveros, F (1988) Centrosema spp. In: Skerman PJ (Ed.) Tropical Forage Legumes 2nd ed. FAO Plant Production and Protection Series, No.2. Rome Italy Pp. 237 - 257. 
Steel, R. C and Torrie, J. H (1980). Principles and procedures of statistics. A Biometrical Approach, $3^{\text {rd }}$ Edition. Mc Graw Hill Book coy; N.Y. U. S.A.

Raharjo, Y.C, Cheeke, P.R, Patton, N.M and Supriyati . K (1986). Evaluation of tropical forages and by-product feeds for rabbit production. Nutrient digestibility and effects of heat treatment. Journal of Applied Rabbit Research, 9: 56-66.

Talapatra, E.L and Price, B.L (1984). Oxalate: Its chemistry and nutritional significance. World Review of Nutrition and Dietetics, Krager, New York. 51-55pp.

Uche, C.P., Iheanacho, A.U., Nwokorobia, C.O., Ahaotu, E.O. and Onuruka, A.U. (2014). Characteristics and Performance of Guinea Fowl Production under Improved and Extensive Management Practices in Two Communities in Imo State, Eastern Nigeria. Inter J. Lib Manage Soc Sci, 2(1): 1-5.

Wilson, H. R (1991). Interrelationships of egg size, post hatching growth and hatchability. Worlds Poultry Science Journal, 47: 5-20.

Yildirim, I. J (2012). Nutrition of guinea fowl breeders: A review. Journal of Animal Science Advances, Vol. 2(2), pp.188-193. 